\title{
Lista de referees - Números 23, 24, 25, 26, 27
}

\section{(2) OpenEdition \\ 1 Journals}

Edição electrónica

URL: https://journals.openedition.org/sociologico/1344

DOI: 10.4000/sociologico.1344

ISSN: 2182-7427

Editora

CICS.NOVA - Centro Interdisciplinar de Ciências Sociais da Universidade Nova de Lisboa

\section{Edição impressa}

Data de publição: 21 dezembro 2015

Paginação: 103

ISSN: 0872-8380

\section{Refêrencia eletrónica}

«Lista de referees - Números 23, 24, 25, 26, 27», Forum Sociológico [Online], 27 | 2015, posto online no dia 31 maio 2016, consultado o 31 março 2022. URL: http://journals.openedition.org/sociologico/ 1344 ; DOI: https://doi.org/10.4000/sociologico.1344

Este documento foi criado de forma automática no dia 31 março 2022.

(c) CICS.NOVA 


\title{
Lista de referees - Números 23, 24,
} $25,26,27$

\author{
ANDRADE, Luciana \\ AQUINO, Cássio A. B. \\ AZEVEDO, Rodrigo Ghiringhelli \\ BRANCO, Rui \\ BURGOS, Marcelo Baumann \\ CHALLINOR, Elizabeth \\ CHAVES, Miguel \\ CURI, Martin \\ DE LEMOS MARTINS, Moisés \\ DELICATO, Ana \\ 1 DIAS, Isabel Correia \\ 2 DIÓGENES, Glória \\ 3 DIOGO, Ana Matias \\ 4 DIOGO, Fernando \\ 5 DIONÍSIO, Bruno \\ 16 DORES, António Pedro \\ 17 FERNANDES, Ana Alexandre \\ 18 FONTES, Margarida \\ 19 FORTUNA, Carlos \\ 20 FRANÇA, Thais \\ 21 FRUGOLI JR, Heitor \\ 22 GUEDES, Simoni Lahud \\ 23 GUERRA, Paula \\ 24 LOPES, João Teixeira
}




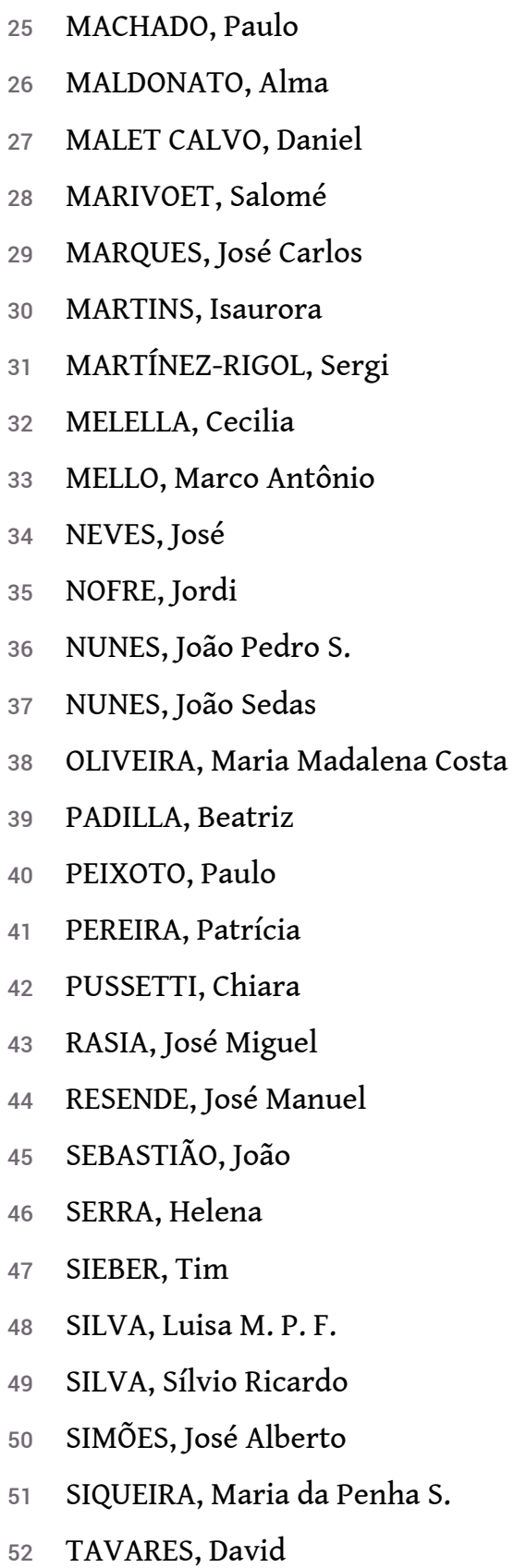

